\title{
КОНТРОЛІНГ ЯК ІНСТРУМЕНТ ПІДТРИМКИ ДОСТАТНЬОГО РІВНЯ ЕКОНОМІЧНОЇ БЕЗПЕКИ ТА КОНКУРЕНТОСПРОМОЖНОСТІ ПРОМИСЛОВОГО ПІДПРИЕМСТВА
}

\author{
Inna Khomenko, Iryna Sadchykova, Mariia Kolotok \\ CONTROLLING AS A TOOL TO MAINTAIN A SUFFICIENT LEVEL \\ OF ECONOMIC SECURITY AND COMPETITIVENESS \\ OF INDUSTRIAL ENTERPRISE
}

\begin{abstract}
У статті розглянуто економічну безпеку діяльності підприємств, ї̈ сутність, основні положення та важливість для функиіонування та розвитку. Також виявлено основні проблеми, які виникають, для підтримки достатнього рівня економічної безпеки та конкурентоспроможності промислового підприємства. Охарактеризовано сутність економічної безпеки як економічної категорії, проведено порівняння вітчизняного та закордонного досвіду підтримки достатнього рівня економічної безпеки. Доведено необхідність оцінки рівня економічної безпеки, основні ї̈ функиії. 3'ясовано, щзо потрібно аналізувати кожне конкретне підприємство і врахувати взаємозв 'язки складових економічної безпеки для визначення основних чинників негативного впливу та окреслення найслабших сторін діяльності підприємства.

Розкрито поняття контролінгу, його мету та функції. Зазначено його основні принципи та методи, наведено взаємозв'язок між ними. Досліджено основні завдання кожного з видів контролінгу, їхню основну мету та зв'язки. Виділено, що на рівень економічної безпеки прачюючих підприємств впливає ефективний контролінг, елементи якого розробляються, плануються і втілюються залежно від особливостей функиіонування підприємства. Зосереджено увагу на важливості інформаційної безпеки діяльності підприємств в Україні. Визначено основні заходи на державному рівні, які посприяють більш якісному функиіонуванні економічної безпеки підприємств та зроблено висновки про ї̈ важливість.
\end{abstract}

Ключові слова: конкурентоспроможність; промислове підприємство; економічна безпека; підходи; управління; контролінг; фактори розвитку економічної безпеки; чинники економічної безпеки.

Рис.: 3. Табл.: 1. Бібл.: 26.

This article considers the economic security of enterprises, its essence, the main provisions and importance for the functioning and development. The main problems that arise to maintain a sufficient level of economic security and the competitiveness of the industrial enterprise are also identified. The essence of economic security as an economic category is characterized, a comparison of domestic and foreign experience of maintaining a sufficient level of economic security is made. The necessity of economic security, its main functions are proved. The economic security of the enterprise is an element of the system of national economic security. It has been proven that it is necessary to analyze each specific enterprise and take into account the relationships of components of economic security to determine the main factors of negative impact and to identify the weakest aspects of the enterprise.

The concept of controlling, its purpose and functions are revealed. Its basic principles and methods are indicated, the interrelation between them is expressed. The main tasks of each type of controlling, their main purpose and connections are studied. The economic security of operating enterprises is influenced by effective controlling, the elements of which are developed, planned and implemented depending on the characteristics of the enterprise. Attention is focused on the importance of information security of enterprises in Ukraine. The main measures at the state level that will contribute to better functioning of economic security of enterprises are identified and conclusions are made about its importance.

Keywords: competitiveness; industrial enterprise; entrepreneur; economic security; factors of economic security development; controlling; factors of economic security.

Fig.: 3. Table: 1 References: 26.

JEL Classification: M11; D23

Постановка проблеми. Нині спостерігається нестабільність економіки та світова рецесія, пов'язані з впливом COVID-19, недоотримання прогнозованих кредитів МВФ, що, у свою чергу, призводить до створення нових проблем на фінансовому ринку країни та загроз для фінансового стану підприємств. Тому всім суб'єктам господарювання важливо вживати правильних заходів щодо покращення процесу виробництва й реалізації, їхнього становища на ринку, економічної незалежності тощо. Насамперед для цього необхідно встановити певну стабільність функціонування, а також приймати зважені рішення щодо управління наявними ресурсами та контролю над виробничими процесами.

Загальною проблемою для діяльності промислових підприємств в Україні $є$ несприятливе економічне та політичне становище. Унаслідок таких глобальних проблем досить складно зберегти стабільність функціонування.

(C) Хоменко I. О., Садчикова I. В., Колоток М. О., 2021 
Аналіз останніх досліджень і публікацій. Теоретичні та практичні аспекти забезпечення економічної безпеки діяльності підприємств розкриваються у роботах М. Бендікова, І. Бєлоусової, Т. Кузенка, Г. Козаченко, А. Одінцова, О. Груніна та ін. Більш глибоким висвітленням цього питання та більш чіткими напрямами розвитку підприємств займались такі науковці, як В. Шликов, М. Камлик, А. Спіфанов, А. Дикий, Н. Підлужна, Т. Ковальов та інші [1-9; 12-16; 18-22; 24-26].

Взагалі економічна безпека - це запобігання внутрішнім і зовнішнім негативним впливам (загрозам) з метою гарантування його ефективного та стабільного функціонування та динамічного соціального розвитку [21].

Г. Пастернак-Таранушенко був одним із перших науковців, який застосував та визначив поняття економічної безпеки підприємств у своїй науковій праці «Економічна безпека держави». Він наголошував на тому, що державу створює суспільство для забезпечення суспільних потреб, потреб населення та окремо кожного громадянина [24]. Отже, має створювати оптимальні умови для підприємницької діяльності, у тому числі забезпечувати економічну безпеку для неї.

Існує декілька підходів до трактування економічної безпеки. Наприклад, О. Грунін визначає економічну безпеку підприємства як певний стан, в якому підприємство має захист від наявних небезпек, може їм запобігти, а також досягає цілі бізнесу в умовах конкуренції [3]. Є. Олейніков у своїй праці «Основи економічної безпеки» розглядав це поняття як «стан найбільш ефективного використання ресурсів для подолання загроз і забезпечення стабільного функціонування підприємства сьогодні і в майбутньому» [16].

Досить чітким є поняття «захищеності» від М. Бендікова - це захищеність науковотехнічного, технологічного, виробничого і кадрового потенціалу підприємства від прямих та непрямих загроз, пов'язаних, наприклад, із неефективною промисловою політикою держави [12]. У схожому контексті подають визначення Д. Ковальова та Т. Сухорукова, які вважають економічну безпеку як «захист діяльність підприємства від негативних впливів зовнішнього середовища, а також здатність швидко усувати загрози або пристосовуватись до них [12].

У роботі Г. Клейнера, В. Тамбовцева, Р. Качалова економічна безпека діяльності підприємства - «це стан підприємства, який означає, що ймовірність небажаної зміни яких-небудь якостей, параметрів власного майна, а також змін його до зовнішнього середовища, є невелика» [12].

Більшість учених вважають, що існує шість основних етапів розвитку економічної безпеки діяльності підприємств в Україні [20]. Перший етап розпочався від прийняття незалежності України, у 1991 році. На цьому етапі це поняття мало на меті збереження комерційних таємниць, секретів підприємства, таємниць інтелектуальної власності тощо.

Уже починаючи з 1998 року це поняття набуло значення певної «захищеності» від загроз зовнішнього середовища підприємства, а у 2002 році економічна безпека ототожнюється з ефективним функціонуванням у разі ризику. 32005 до сьогодення економічна безпека вже розглядається окремо в кожній галузі, до якої відноситься підприємство, що дозволяє значно розширити ії можливості.

Виділення недосліджених частин загальної проблеми. У розглянутих вище дослідженнях розкрито багато теоретичних і практичних питань, пов'язаних із контролінгом та запропоновано напрями підвищення ефективності його впровадження. Водночас ця проблема контролінгу з позицій економічної безпеки в практиці підприємств не достатньо вивчена, що вимагає подальшого дослідження теоретичних основ і розробки методичних аспектів щодо його застосування на підприємствах. 
ТЕОРЕТИЧНІ ПРОБЛЕМИ РОЗВИТКУ НАЦІОНАЛЬНОЇ ЕКОНОМІКИ

Мета дослідження. Метою цієї статті є всебічне розкриття сутності контролінгу як інструменту підтримки достатнього рівня економічної безпеки та конкурентоспроможності промислових підприємств, виявлення основних чинників, які можуть на неї впливати та методів регулювання. Визначено спрямованість контролінгу як інструменту для досягнення економічної безпеки діяльності підприємства.

Виклад основного матеріалу. У статті використано такі методи, як абстрагування, тобто уявне відтворення зв'язків, відносин між предметами дослідження, та виділення декількох його сторін для створення певної моделі; метод аналізу, тобто вивчення об'єкту дослідження по частинам з характеристикою цієї самої конкретної частини; метод синтезу, який полягає в з'єднанні частин одного об'єкта в одне ціле для розглядання його загалом; узагальнюються методи абстрагування, ідеалізації, формалізація, аналіз, синтез, індукція, дедукція, аксіоматика, узагальнення тощо. Завдяки поєднанням цих методів проводилось логічне дослідження зібраних фактів, вироблення понять, думок, робляться висновки.

Результати дослідження та обговорення. Підприємство - це організаційно відокремлена, економічно самостійна ланка виробничої сфери економіки, що спеціалізується на виготовленні продукції, виконанні робіт і наданні послуг. Головне завдання підприємства полягає у задоволенні потреб ринку в його продукції або послугах з метою одержання прибутку [8].

Суб'єктами підприємницької діяльності виступають фізичні особи - громадяни України та юридичні особи будь-якої форми власності.

3 своїми масштабами підприємства поділяються на малі (валовий продукт яких до 10 млн євро), середні (від 11 млн євро до 50 млн євро) та великі (від 50 млн євро). В Україні переважають малі підприємства (див. табл.), саме вони сприяють появі великої кількості нових робочих місць, впровадженню нових технологій виробництва тощо.

Таблиця

Динаміка кількості підприємств в Україні за 5 років

\begin{tabular}{|c|c|c|c|c|}
\hline Рік & Кількість підприсмств, одиниць & Великі, \% & Середні, \% & Малі, \% \\
\hline 2015 & 343440 & 0,1 & 4,4 & 95,5 \\
\hline 2016 & 306369 & 0,1 & 4,9 & 95 \\
\hline 2017 & 338256 & 0,1 & 4,4 & 95,5 \\
\hline 2018 & 355877 & 0,1 & 4,5 & 95,4 \\
\hline 2019 & 380597 & 0,1 & 4,7 & 95,2 \\
\hline
\end{tabular}

Джерело: складено авторами на основі джерела [7].

32016 року кількість підприємств в Україні збільшується. Проте, якщо оцінювати динаміку за 10 років, то вона є досить нерівномірною.

На цю динаміку впливає низка різних зовнішньоекономічних факторів, таких як: наявність необхідних ресурсів, наявність технологій виробництва, ефективність політики держави для функціонування підприємств, розвиток ринку кредитних послуг, наявність часу та простору (швидкість обміну інформацією, експорт/імпорт тощо), конкурентоспроможність, наявність підприємницьких здібностей.

Економічна безпека діяльності підприємств дозволяє мінімізувати вплив зовнішніх факторів та навколишнього середовища, допомагає пристосуватися до умов, які можуть негативно впливати на нього, а також усунення загроз або їх запобігання.

Загалом економічна безпека діяльності підприємств має широкий спектр дій. Це представлено на нижченаведеній схемі (рис. 1). 


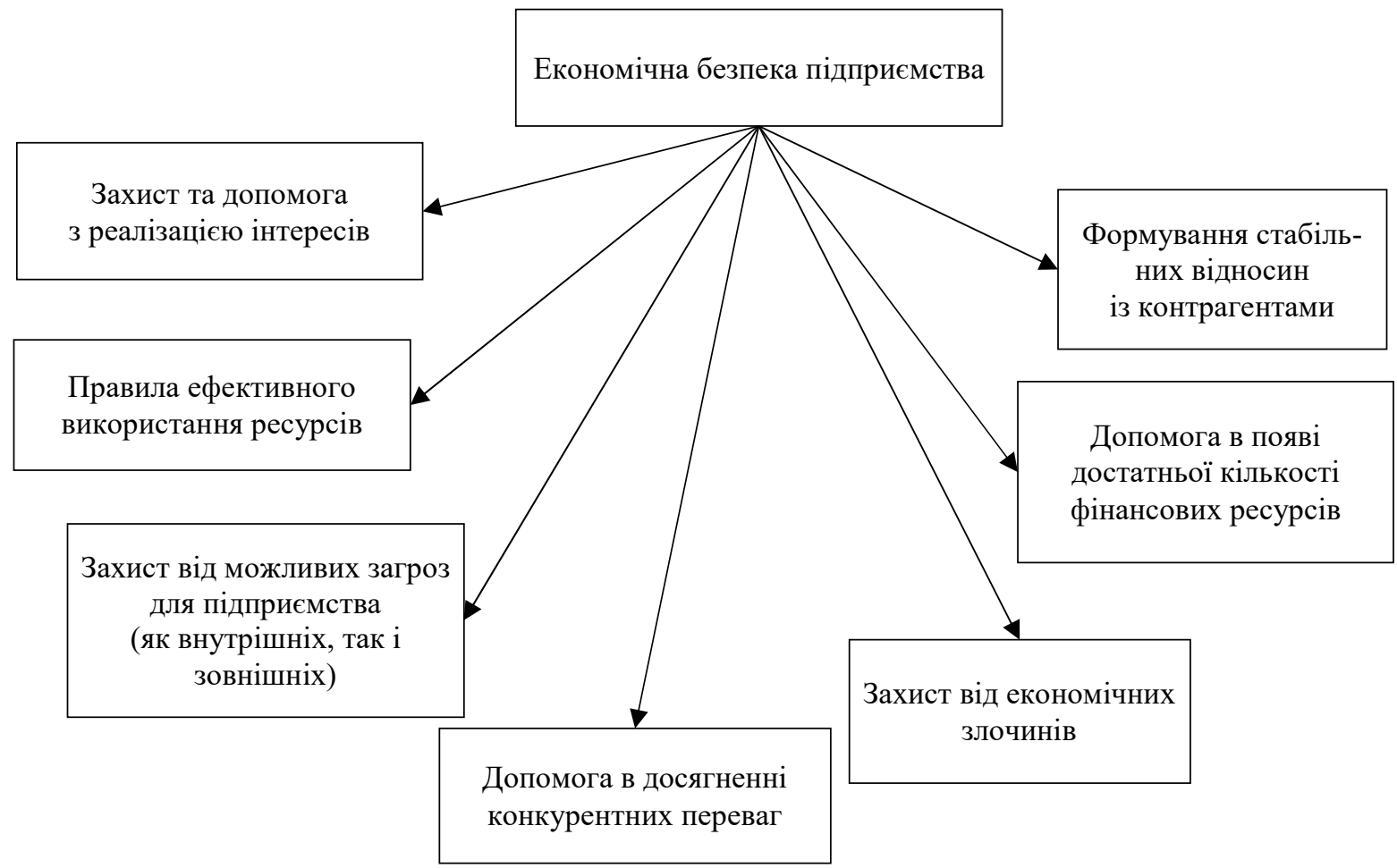

Рис. 1. Підходи до визначення поняття «економічна безпека підприємства» Джерело: складено авторами на основі [15].

Незважаючи на напрям діяльності підприємства, основною його метою є отримання прибутку. Новим явищем у теорії управління є контролінг. Контролінг являю собою систему управління прибутком та допомагає зорієнтуватися при досягненні необхідних цілей.

Система контролінгу - це принципово нова концепція інформації і управління, яку можна визначити як обліково-аналітичну систему, що реалізує синтез елементів обліку, контролю, планування, яка забезпечує як оперативне, так і стратегічне управління процесом досягнення цілей і результатів діяльності підприємства [4].

Крім уже названих функцій, контролінг має такі [19]:

1) надання інформаційної підтримки у процесі прийняття рішень;

2) створення загальної системи в управлінні підприємством;

3) забезпечення раціональності управлінського процесу.

А також однією із основних функцій є забезпечення економічної безпеки діяльності підприємства.

Контролінг забезпечує служба контролінгу. Також може створюватись як робоча група або окремий підрозділ підприємства. Враховуючи те, що контролінг надає достатньо вагому підтримку для підприємств, дає змогу вистояти в конкурентній боротьбі, наділяє необхідною інформацією для розширення підприємства на ринку, можна стверджувати, що дана система є деякою опорою для становлення на ринку [22; 23].

Також якщо узагальнити всі думки вчених, можна виділити 4 основних види контролінгу:

1) стратегічний;

2) тактичний;

3) оперативний;

4) диспозитивний.

Стратегічний контролінг має на меті забезпечення виживання підприємства, проведення антикризової політики та підтримує потенціал успіху. Однією із ключових переваг є те, що він охоплює як зовнішнє, так і внутрішнє середовища підприємства. 
ТЕОРЕТИЧНІ ПРОБЛЕМИ РОЗВИТКУ НАЦІОНАЛЬНОЇ ЕКОНОМІКИ

Головними завданнями стратегічного контролінгу є [14]:

1) встановлення якісних та кількісних цілей підприємства;

2) формування та відповідальність за стратегічне планування;

3) розробка альтернативних стратегій (у разі необхідності);

4) визначення слабких місць підприємства;

5) аналіз інновацій та інвестицій;

6) визначення основних підконтрольних показників у відповідності з встановленими стратегічними цілями;

7) порівняння планових (нормативних) і фактичних значень підконтрольних показників 3 метою виявлення причин, винних і наслідків даних відхилень;

8) визначення критичних зовнішніх і внутрішніх умов, які лежать в основі стратегічних планів.

Ще однією, не менш важливою перевагою стратегічного контролінгу є те, що він спрямований на середньо- та довгостроковий період.

Взагалі стратегічний контролінг спрямований на виконання стратегії підприємства, досягнення його основної мети, а також забезпечує ліквідність підприємства.

Тактичний контролінг забезпечує прибутковість та ліквідність компанії. На відміну від стратегічного, він діє лише у внутрішньому середовищі підприємства.

Тактичний контролінг також має низку завдань, які він виконує на підприємстві, а саме [17]:

1) контролює тактичні показники відповідно до встановлених цілей;

2) контролює розробку та організацію тактичних планів;

3) порівнює планові та фактичні показники тактичного управління;

4) визначає вузькі місця тактичного управління;

5) створює та розвиває систему інформаційного забезпечення тактичного управління.

Основна складова тактичного контролінгу - планування, бюджетування, внутрішній аудит, аналіз та консалтинг.

Оперативний контролінг, так само як і тактичний, спрямований на забезпечення прибутковості та ліквідності. Проте відрізняється завданнями, які на нього покладені [14]:

1) контроль та керівництво при плануванні та розробці бюджету;

2) визначення всієї сукупності підконтрольних показників відповідно до встановлених плинних цілей;

3) порівняння планових (нормативних) і фактичних показників підконтрольних результатів і витрат з метою виявлення причин, винних і наслідків відхилень;

4) аналіз впливу відхилень на виконання плинних планів;

5) мотивація і створення систем інформації для прийняття плинних управлінських рішень.

Також, на відміну від стратегічного контролінгу, оперативний більше спрямований на короткостроковий період та має конкретні часові рамки.

Диспозитивний контролінг пропонує заходи, у разі якщо поточна діяльність підприємства змінюється, і необхідно обрати правильні рішення для досягнення оперативних цілей. Також диспозитивний контролінг відрізняється від інших тим, що реалізується протягом усього терміну існування системи контролінгу на підприємстві [25].

Однак дуже важливо розрізняти кожен із цих видів, оскільки у кожного $є$ своя мета та свої завдання. А також дуже важливо знати, як пов’язані між собою (рис. 2). 
ТЕОРЕТИЧНІ ПРОБЛЕМИ РОЗВИТКУ НАЦІОНАЛЬНОЇ ЕКОНОМІКИ

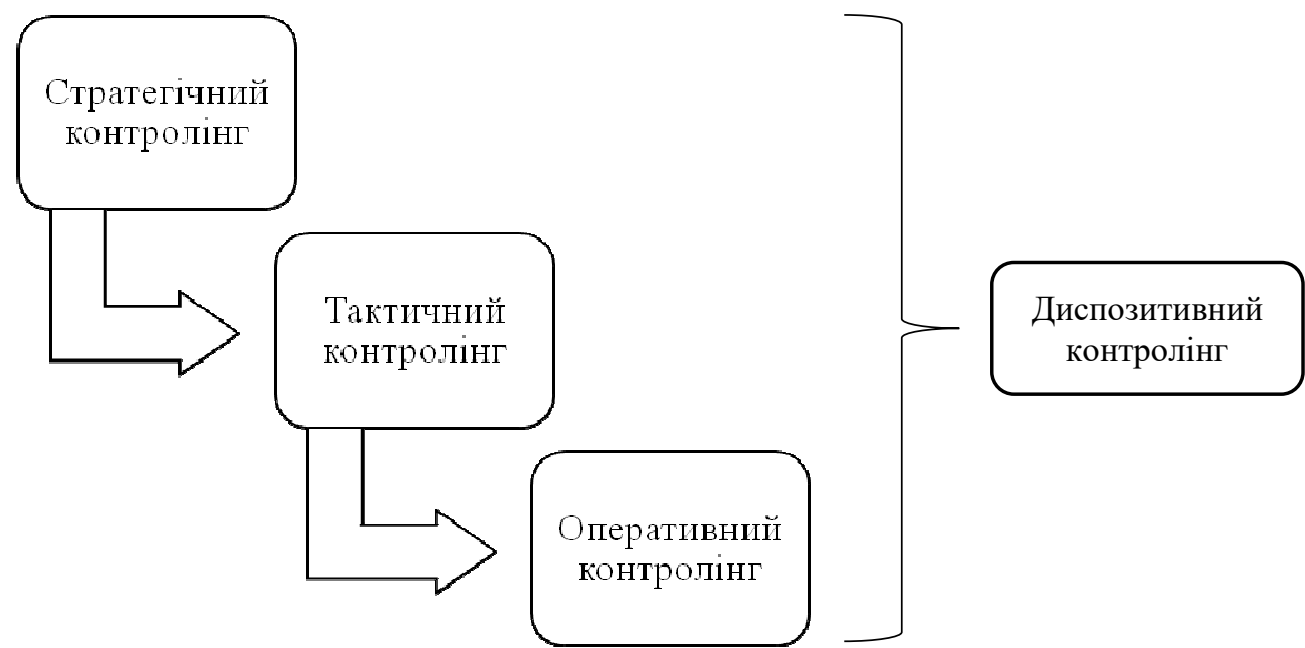

Рис. 2. Взаємозв'язок видів контролінгу

Джерело: складено авторами на основі джерела [25].

Якщо говорити про сучасну концепцію контролінгу, то його функції тісно пов'язані 3 його методами. Методи, або інструменти контролінгу використовуються для забезпечення управлінських цілей стійким розвитком. До таких методів належать [1]:

1. SWOT-аналіз - використовується для визначення сильних та слабких сторін проекту підприємства, визначення його можливостей та можливих загроз.

2. PEST-аналіз - використовується для визначення різноманітних аспектів (соціальних, технологічних, політичних, економічних) зовнішнього середовища.

3. GAP-аналіз - використовується для розуміння чого фактично може досягти підприємство при незмінній політиці та визначає, що необхідно в ній змінити для бажаного розвитку.

4. ABS-аналіз - використовується для класифікації ресурсів фірми залежно від їх значення.

Також сюди належать функціонально-вартісний аналіз, портфельний аналіз, аналіз сценаріїв, портфоліо-аналіз, аналіз конкурентних переваг тощо.

Ці всі функції та методи є невід’ємною складовою контролінгу, який забезпечує контроль, аналіз, планування, інформаційне забезпечення, адаптивність, цілеспрямованість, стратегічну орієнтацію тощо для підприємства.

Проте варто зазначити, що система контролінгу має бути адаптована до факторів зовнішнього та внутрішнього середовища підприємства. До чинників зовнішнього середовища належать вимоги законодавства, політика країни, ринки збуту та постачання, а до внутрішнього - масштаби підприємства, виробнича програма, організація підприємства, стиль керівництва. Це важливо для більш точної системи управління та більш якісного забезпечення підприємства економічною безпекою.

Основне завдання контролінгу - направлення управлінської політики на досягнення цілей підприємства, а також захист від впливу чинників зовнішнього та внутрішнього середовища.

Для узагальнення інформації щодо контролінгу, сформуємо схему контролінгу, як управлінням потенціалом економічної безпеки діяльності підприємства (рис. 3).

Економічна безпека є спільною проблемою і для підприємства, і для держави. Оскільки держава, використовуючи різноманітні методи, істотно впливає на її формування, при цьому безпосередньо втручаючись у цей процес, необхідно зосередити увагу на тому, щоб не завдати шкоди для діяльності самого підприємства [26]. Для цього варто зосередити увагу на законодавчій базі та в разі потреби ввести нові законодавчі акти з метою уникнення неправомірних дій щодо захисту себе свого підприємства з боку підприємця. 
ТЕОРЕТИЧНІ ПРОБЛЕМИ РОЗВИТКУ НАЦІОНАЛЬНОЇ ЕКОНОМІКИ

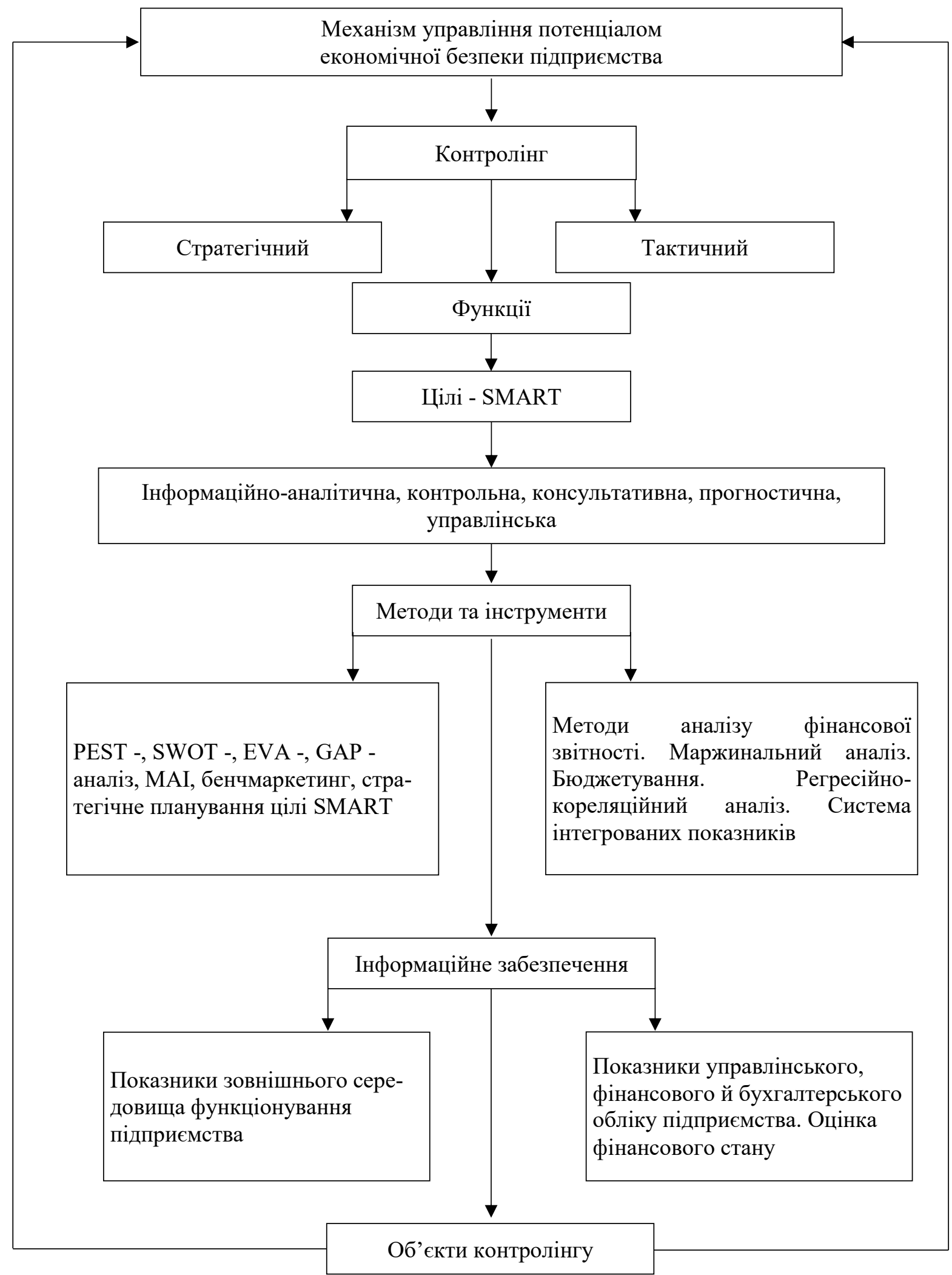

Рис. 3. Система контролінгу підприємства

Джерело: складено авторами на основі джерела [13].

В умовах євроінтеграції важливим фактором зовнішнього впливу на економічну безпеку підприємства $є$ міграційні процеси. За межі України виїжджає найбільш працездатна частина населення, зменшуючи пропозицію на ринку праці України [11]. Як пра- 
вильно зазначає I. Кичко, що для збереження трудового потенціалу, сприяння економічній безпеці підприємств в частині забезпечення кваліфікованою робочою силою, необхідно зосередити увагу на мотиваційному факторі залучення персоналу [10].

На сьогодні Україна потребує інноваційного розвитку, що буде сприятливо впливати на розвиток підприємства. Варто зазначити, що створення інноваційного клімату потребує значних змін в інституційному середовищі ведення бізнесу, активізації різноманітних досліджень та розробок, активно використовувати інформаційні та комунікаційні технології тощо [12]. Але при неправильному веденні політики, спрямованої на інноваційний розвиток, можливе виникнення низки загроз для діяльності підприємств, у тому числі і їх економічної безпеки.

Щодо закордонного досвіду, то такі країни, як, наприклад, США, Німеччина та Японія, то вони мають чітко закріплені права підприємств та механізми їх реалізації, що визначає стійку законодавчу базу, а також намагаються створити максимально сприятливе середовище для діяльності підприємств [6]. До того ж вони мають достатньо розвинену страхову сферу, яка виступає головним ризикознижуючим чинником. На жаль, в Україні цим аспектам приділяється недостатня увага.

Країни Західної Свропи застосовують стимулюючу функцію оподаткування та створюють сприятливі фінансово-економічні умови для інвестицій. У результаті цього підвищується інвестиційна привабливість цих підприємств, а це, у свою чергу, підвищує їх економічну безпеку [6].

Нині в Україні спостерігається низка невирішених проблем, пов'язаних з економічною безпекою, таких як: банкрутство підприємств через неефективність використання ресурсів; нестійкість підприємств до конкуренції; неконтрольована приватизація; відсутність прозорої податкової політики.

Для покращення стану економічної безпеки підприємств необхідно чітко відібрати методи, які будуть максимально впливати на іiі розвиток. Одним із таких методів є моделювання, що дасть змогу яскраво оцінити всі чинники навколишнього середовища підприємств та максимально весь їх вплив на них.

Висновки та пропозиції. Економічна безпека підприємства $є$ елементом системи національної економічної безпеки. Отже, можна зробити висновок, що українські підприємства мають низький рівень економічної безпеки і це тісно залежить від досягнення економічної безпеки всієї держави, грунтується на фінансовому, управлінському та виробничому потенціалі та перспективах їх розвитку.

Також підтримка певного рівня економічної безпеки діяльності та конкурентоспроможності промислових підприємств залежить від самого підприємства, а саме від його територіального розміщення, наявних ресурсів, трудового, логістичного й маркетингового потенціалу та інших факторів. Потрібно аналізувати кожне конкретне підприємство і врахувати взаємозв'язки складових економічної безпеки для визначення основних чинників негативного впливу та окреслення найслабших сторін діяльності підприємства.

До основних спрямованих заходів зі сторони держави доцільно прийняття відповідних законодавчих актів для врегулювання економічної безпеки. Орієнтуючись на іноземний досвід можна взяти до уваги вдосконалення страхової сфери для зменшення ризиків, а також зробити прозорою податкову політику. Зі сторони підприємців можна більш відповідально ставитись до виходу на ринок, краще вивчати конкурентів, розроблювати чітку стратегію тощо.

Високий рівень економічної безпеки діяльності та конкурентоспроможності підприємств дасть змогу промисловим підприємствам стати більш стійкими на ринку та розкриє перспективи для розвитку нових галузей виробництва. 
ТЕОРЕТИЧНІ ПРОБЛЕМИ РОЗВИТКУ НАЦІОНАЛЬНОЇ ЕКОНОМІКИ

\section{Список використаних джерел}

1. Бердар М. М. Контролінг як сучасна концепція управління промисловим підприємством. Економіка та держава. 2016. № 11. С. 39-43. URL: http://www.economy.in.ua/pdf/11_2016/10.pdf.

2. Бєлєнкова О. Ю. Сутність оперативного контролінгу та його роль в управлінні підприємством. Ефективна економіка. 2018. № 4. URL: http://www.economy.nayka.com.ua/?op=1\&z=6242.

3. Грунин О. А., Грунин С. О. Экономическая безопасность организации. Санкт-Петербург, 2002. $160 \mathrm{c}$.

4. Давидович I. Є. Контролінг : навч. посіб. Київ, 2008. 552 с. URL: https://pidru4niki.com/ 14170120/finansi/ponyattya_pro_kontroling_yogo_sut_znachennya.

5. Данілова Е. І. Концепція системного підходу до управління економічною безпекою підприємства: монографія. Вінниця : Європейська наукова платформа, 2020. 342 с.

6. Денисенко М. П. Зарубіжний досвід регулювання економічної безпеки. Економічна наука. 2017. Вип. 1. С. 17. URL: http://www.investplan.com.ua/pdf/6_2017/5.pdf.

7. Державна служба статистики України : офіційний сайт. URL: http://www.ukrstat.gov.ua.

8. Економіка та організація виробництва : навчальний посібник / уклад. I. В. Причепа, Л. П. Руда. Вінниця : ВНТУ, 2017. 186 с. URL: https://web.posibnyky.vntu.edu.ua/fmib/ 35prychepa_ekonomika_ta_organizaciya_vyrobnictva/index.html.

9. Економічна безпека та фінансові розслідування: концепти, прагматика, інструментарій та забезпечення : колективна монографія / за ред. д.е.н., доц. Вівчар О. І. Варналій 3. С. Тернопіль, 2019. $395 \mathrm{c}$.

10. Кичко I. І. Реалізація трудового потенціалу АПК в умовах євроінтеграції. Стратегія розвитку Украйни: фінансово-економічний та гуманітарний аспекти: матеріали V Міжнародної науково-практичної конференції. Київ : Інформаційно-аналітичне агентство, 2018. С. 21-23.

11. Кичко I. І., Тимошенко О. В., Кліщ Д. М. Перспективи збереження трудового потенціалу в контексті євроінтеграції. Формування ринкових відносин в Україні. 2018. № 11. C. 99-108. URL: http://nbuv. gov. ua/UJRN/frvu_2018_11_18.

12. Комарков Д. В. Забезпечення економічної безпеки розвитку підприємства : дис...канд. екон. наук / Харківський національний університет імені Семена Кузнеця. Харків, 2019. 257 с. URL: https://www.hneu.edu.ua/wp-content/uploads/2019/06/Komarkov-D.V.-Disertaciya-Vchenarada-D-64.055.01-2019.pdf.

13. Копча Ю. Ю. Особливості контролінгу в системі управління формуванням потенціалу економічної безпеки підприємства. Економічний вісник Дніпровської політехніки. 2019. № 1 (65). C. 139-148.

14. Маркіна І. А., Таран-Лала О. М., Гунченко М. В. Контролінг для менеджерів. Київ, 2013. 304 c. URL: https://pidru4niki.com/1584072054348/finansi/kontroling_dlya_menedzheriv.

15. Небава М. І., Міронова Ю. В. Економічна безпека підприємства : навчальний посібник / уклад. М. І. Небава, Ю. В. Міронова. Вінниця : ВНТУ, 2017. 75 с. URL: https://web.posibnyky.vntu.edu.ua/fmib/33nebava_ekonomichna_bezpeka_pidpriyemstva/rozd1.html.

16. Олейников Е. А. Основы экономической безопасности. Москва, 1997. 233 с.

17. Попов С. А. Стратегический менеджмент: актуальный курс : учебник для бакалавриата и магистратуры. Москва, 2019. 463 с.

18. Салоїд С. В. Організаційно-економічний механізм управління економічною безпекою підприємств машинобудування : дис. канд. екон. наук : 08.00.04 / Національний технічний університет України «Київський політехнічний інститут імені Ігоря Сікорського». Київ, 2019. 305 с.

19. Сопко В. В., Ромашко О. Н. Контролінг як засіб забезпечення системи економічної безпеки підприємства. Актуальні проблеми економіки. $2012 . \quad$ № 2. С. 176-179. URL: http://nbuv.gov.ua/UJRN/ape_2012_2_21.

20. Сосновська I. М. Поняття та значення економічної безпеки виробничо-господарської діяльності підприємств. Ефективна економіка. 2015. № 9. URL: http://www.economy.nayka.com.ua/ ?op $=1 \& z=4303$.

21. Суліма Н. М., Степасюк Л. М., Величко О. В. Економіка і фінанси підприємства: підручник. Київ, 2015. 466 c. URL: https://pidru4niki.com/84386/ekonomika/ekonomichna_bezpeka_pidpriyemstva. 
22. Хоменко I. О. Економічна безпека транспортних кластерів. Кониептуальні засади формування фінансово-економічної безпеки : колективна монографія. Ніжин, 2015. С. 426-438.

23. Хоменко I. О., Концева В. В., Бойко Н. В. Методичні аспекти превентивного антикризового управління та оцінювання фінансового стану суб'єктів господарювання. Фінансові дослідження. 2016. № 1 (1). C. 105-117. URL: http://nbuv.gov.ua/UJRN/find_2016_1_16.

24. Чешук В.О., Полінкевич О. М. Суть та значення економічної безпеки підприємств у новій економіці. Економічний часопис Східноєвропейського національного університету імені Лесі Українки. 2017. № 3(11). С. 52-56.

25. Швидка О. П. Види контролінгу та підприємстві та їх взаємозв'язок. Ефективна економіка. 2013. № 12. URL: http://www.economy.nayka.com.ua/?op=1\&z=2645.

26. Юрович Л. О. Економічна безпека підприємства: сутність, чинники впливу, основні проблеми. 66-та студентська науково-технічна конференція : збірка тез доповідей. Львів, 2009. С. 234-237. URL: http://ena.lp.edu.ua:8080/bitstream/ntb/4894/1/95.pdf.

\section{References}

1. Berdar, M.M. (2016). Kontrolinh yak suchasna kontseptsiia upravlinnia promyslovym pidpryiemstvom [Controlling as a modern concept of industrial enterprise management]. Ekonomika ta derzhava - Economy and state, (11), 39-43. http://www.economy.in.ua/pdf/11_2016/10.pdf.

2. Bielienkova, O.Yu. (2018). Sutnist operatyvnoho kontrolinhu ta yoho rol v upravlinni pidpryiemstvom [The essence of operational controlling and its role in enterprise management]. Efektyvna ekonomika - Efficient economy, (4). http://www.economy.nayka.com.ua/?op=1\&z=6242.

3. Grunin, O.A., \& Grunin, S.O. (2002). Eonomicheskaia bezopasnost organizatsii [Economic security of the organization]. Piter.

4. Davydovych, I.Ye. (2008). Kontrolinh [Controlling]. https://pidru4niki.com/14170120/finansi/ ponyattya_pro_kontroling_yogo_sut_znachennya.

5. Danilova, E.I. (2020). Kontseptsiia systemnoho pidkhodu do upravlinnia ekonomichnoiu bezpekoiu pidpryiemstva [The concept of a systematic approach to managing the economic security of the enterprise]. Yevropeiska naukova platforma.

6. Denysenko, M.P. (2017). Zarubizhnyi dosvid rehuliuvannia ekonomichnoi bezpeky [Foreign experience in regulating economic security]. Ekonomichna nauka - Economics, 1, 17. http://www.investplan.com.ua/pdf/6_2017/5.pdf.

7. Derzhavna sluzhba statystyky Ukrainy: ofitsiinyi sait [State Statistics Service of Ukraine: official website] (n.d.). http://www.ukrstat.gov.ua.

8. Prychepa, I.V., \& Ruda, L.P. (2017). Ekonomika ta orhanizatsiia vyrobnytstva [Economics and organization of production]. VNTU. https://web.posibnyky.vntu.edu.ua/fmib/ 35prychepa_ekonomika_ta_organizaciya_vyrobnictva/index.html.

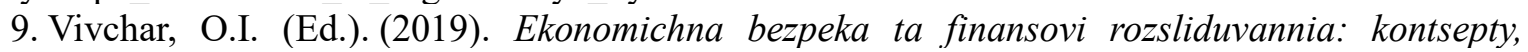
prahmatyka, instrumentarii ta zabezpechennia [Economic security and financial investigations: concepts, pragmatics, tools and support].

10. Kychko, I.I. (2018). Realizatsiya trudovoho potentsialu APK v umovakh yevrointehratsiyi [Realization of labor potential of agro-industrial complex in the conditions of European integration]. In Stratehiia rozvytku Ukrainy: finansovo-ekonomichnyi ta humanitarnyi aspekty: materialy $V$ Mizhnarodnoyi naukovo-praktychnoyi konferentsiyi - Strategy for the development of Ukraine: financial, economic and humanitarian aspects: materials of the V International Scientific and Practical Conference (pp. 21-23). Informatsiyno-analitychne ahentstvo.

11. Kychko, I.I., Tymoshenko, O.V., \& Klishch, D.M. (2018). Perspektyvy zberezhennya trudovoho potentsialu $\mathrm{v}$ konteksti yevrointehratsiyi [Prospects for preserving labor potential in the context of European integration]. Formuvannia rynkovykh vidnosyn v Ukraini - Formation of market relations in Ukraine, (11), 99-108. http://nbuv.gov.ua/UJRN/frvu_2018_11_18.

12. Komarkov, D.V. (2019). Zabezpechennia ekonomichnoi bezpeky rozvytku pidpryiemstva [Ensuring economic security of enterprise development] [PhD dissertation, Kharkiv National Economic University named after S. Kuznets]. https://www.hneu.edu.ua/wp-content/uploads/2019/06/ Komarkov-D.V.-Disertaciya-Vchena-rada-D-64.055.01-2019.pdf. 
ТЕОРЕТИЧНІ ПРОБЛЕМИ РОЗВИТКУ НАЦІОНАЛЬНОЇ ЕКОНОМІКИ

13. Kopcha, Yu.Yu. (2019). Osoblyvosti kontrolinhu v systemi upravlinnia formuvanniam potentsialu ekonomichnoi bezpeky pidpryiemstva [Features of controlling in the management system of the formation of the potential of economic security of the enterprise]. Ekonomichnyi visnyk Dniprovskoi politekhniky - Economic Bulletin of the Dnieper Polytechnic, (1(65)), 139-148.

14. Markina, I.A., Taran-Lala, O.M., \& Hunchenko, M.V.(2013). Kontrolinh dlia menedzheriv [Controlling for managers]. https://pidru4niki.com/1584072054348/finansi/kontroling dlya menedzheriv.

15. Nebava, M.I., \& Mironova, Yu.V. (2017). Ekonomichna bezpeka pidpryiemstva [Economic security of the enterprise]. VNTU. https://web.posibnyky.vntu.edu.ua/fmib/33nebava ekonomichna bezpeka pidpriyemstva/rozd1.html.

16. Oleinikov, E.A. (1997). Osnovy ekonomicheskoi bezopasnosti [Fundamentals of economic security]. Intel-Sintez.

17. Popov, S.A. (2019). Strategicheskii menedzhment: aktualnyi kurs [Strategic management: a current course]. Izdatelstvo Iurait.

18. Saloid, S.V. (2019). Orhanizatsiino-ekonomichnyi mekhanizm upravlinnia ekonomichnoiu bezpekoiu pidpryiemstv mashynobuduvannia [Organizational and economic mechanism of management of economic safety of machine-building enterprises] [PhD dissertation, National Technical University of Ukraine "Kyiv Polytechnic Institute named after Igor Sikorsky"].

19. Sopko, V.V., \& Romashko, O.N. (2012). Kontrolinh yak zasib zabezpechennia systemy ekonomichnoi bezpeky pidpryiemstva [Controlling as a means of ensuring the system of economic security of the enterprise]. Aktualni problemy ekonomiky - Current economic problems, (2), 176-179. http://nbuv.gov.ua/UJRN/ape_2012_2_21.

20. Sosnovska, I.M. (2015). Poniattia ta znachennia ekonomichnoi bezpeky vyrobnychohospodarskoi diialnosti pidpryiemstv [The concept and importance of economic security of production and economic activity of enterprises]. Efektyvna ekonomika - Efficient economy, (9). http://www.economy.nayka.com.ua/?op=1\&z=4303.

21. Sulima, N.M., Stepasiuk, L.M., \& Velychko, O.V. (2015). Ekonomika i finansy pidpryiemstva [Economics and finance of the enterprise]. TsP "Komprynt". https://pidru4niki.com/84386/ekonomika/ ekonomichna_bezpeka_pidpriyemstva.

22. Khomenko, I.O. (2015). Ekonomichna bezpeka transportnykh klasteriv [Economic security of transport clusters]. In Kontseptualni zasady formuvannia finansovo-ekonomichnoi bezpeky - Conceptual principles of formation of financial and economic security (pp. 426-438). Lukianenko V. V.: Orkhideia.

23. Khomenko, IO., Kontseva, V.V., \& Boiko, N.V. (2016). Metodychni aspekty preventyvnoho antykryzovoho upravlinnia ta otsiniuvannia finansovoho stanu subiektiv hospodariuvannia [Methodical aspects of preventive crisis management and assessment of the financial condition of business entities]. Finansovi doslidzhennia - Financial researches, (1(1)). http://nbuv.gov.ua/UJRN/find_2016_1_16.

24. Cheshuk, V.O., \& Polinkevych, O.M. (2017). Sut ta znachennia ekonomichnoi bezpeky pidpryiemstv u novii ekonomitsi [The essence and importance of economic security of enterprises in the new economy]. Ekonomichnyi chasopys Skhidnoievropeiskoho natsionalnoho universytetu imeni Lesi Ukrainky - Economic Journal of the Lesia Ukrainka East European National University, (3(11)), 52-56. https://echas.vnu.edu.ua/index.php/echas/article/view/65/42.

25. Shvydka, O.P. (2013). Vydy kontrolinhu ta pidpryiemstvi ta yikh vzaiemozviazok [Types of controlling and enterprise and their relationship]. Efektyvna ekonomika-Efficient economy, (12). http://www.economy.nayka.com.ua/?op=1\&z=2645.

26. Yurovych, L.O. (2009). Ekonomichna bezpeka pidpryiemstva: sutnist, chynnyky vplyvu, osnovni problemy [Economic security of the enterprise: essence, factors of influence, main problems]. In 66-ta studentska naukovo-tekhnichna konferentsiia. Sektsiia «Ekonomika i menedzhment»-66th student scientific and technical conference. Section "Economics and Management": a collection of abstracts (pp. 234-237). http://ena.lp.edu.ua:8080/bitstream/ntb/4894/1/95.pdf 
|Хоменко Інна Олександрівна - доктор економічних наук, професор, професор кафедри теоретичної та прикладної економіки, Національний університет «Чернігівська політехніка» (вул. Шевченка, 95, м. Чернігів, 14035, Україна).

Khomenko Inna - Doctor of Economics, Professor, Professor of the Department of Theoretical and Applied Economics, Chernihiv Polytechnic National University (95 Shevchenka Str., 14035 Chernihiv, Ukraine).

E-mail: innakhomenko28@gmail.com

ORCID: https://orcid.org/0000-0002-0839-4636

ResearcherID: F-3881-2014

Садчикова Ірина Володимирівна - кандидат економічних наук, доцент, доцент кафедри фінансів, банківської справи та страхування, Національний університет «Чернігівська політехніка» (вул. Шевченка, 95, м. Чернігів, 14035, Україна).

Sadchykova Iryna - PhD in Economics, Associate Professor, Associate Professor of the Department of Finance, Banking and Insurance, Chernihiv Polytechnic National University (95 Shevchenka Str., 14035 Chernihiv, Ukraine).

E-mail: aspirant_chstu@ukr.net

ORCID: https://orcid.org/0000-0001-5144-1306

Колоток Марія Олегівна - бакалавр, Національний університет «Чернігівська політехніка» (вул. Шевченка, 95, м. Чернігів, 14035, Україна).

Kolotok Mariia - Bachelor, Chernihiv Polytechnic National University (95 Shevchenka Str., 14035 Chernihiv, Ukraine).

E-mail: masha_kolotok@ukr.net 